DOI: https://doi.org/10.32839/2304-5809/2019-11-75-182

UDC 781.7

Pyzhianova Nataliia

Pavlo Tychyna Uman State Pedagogical University

\title{
ANALYSIS OF SPECIFIC FEATURES OF SONG FOLKLORE IN POLTAVA REGION.AN ATTEMPT TO GENERALIZE
}

Summary. The article analyzes the scientific works of domestic researchers of folklore of Poltava region. The author systematizes the list of historical references to ritual and non-ritual folklore by chronological and geographical features. The genres of song folklore in the female, male and children's repertoire with justification of specific performance characteristics in the region are distinguished. The types of text invoice presentation of many-voice songs and the peculiarities of singing one-voice songs are analyzed.

Keywords: Poltavaregion, ritualfolklore, non- ritualfolklore, performance, specificity.

Пиж’янова Н.В.

Уманський державний педагогічний університет імені Павла Тичини

\section{АНАЛІЗ СПЕЦИФІЧНИХ ОЗНАК ПІСЕННОГО ФОЛЬКЛОРУ НА ПОЛТАВЩИНІ. СПРОБА УЗАГАЛЬНЕННЯ}

Анотація. У статті аналізуються наукові праці вітчизняних дослідників фрольклору Полтавського регіону. Автором систематизовано перелік історичних згадок про обрядовий та поза обрядовий фольклор за хронологічними та географічними ознаками. Проаналізовано типи фрактурного викладу багатоголосних пісень та особливості виконання пісень одноголосних.Вказується, щобагатоголосн іпісні Полтавщини, переважно, належать до не обрядової лірики та до жіночого репертуару.Зазначається, що сольне виконавство зустрічаеться рідко та відноситься здебільшого до поза обрядової сфрери пісенного фрольклору та до жіночого виконавства. Вказуеться, що як і у більшості районів Середньої Наддніпрянщини виокремлюються пісні гомодонно-гармонічного та поліфонічного складу. Встановлено, що пісні на три голоси представляють собою терцієву втору з октавним дублюванням мелодії, де основа (бас) та мелодія (підголосок) утворюють октави, а середній голос проводиться терщією вищеоснови (баса). Таким чином, пісні на три голоси вирізняються чітко окресленим басом (нижнім голосом, не обов'язково чоловічим - частіше жіночим), середнім голосом, який виконуе функцію основної мелодії та верхній голос, функцією якого є мелізматичне оздоблення основного, середнього голосу. Виокремлено жанри пісенного фольклору у жіночому, чоловічому та дитячому репертуарі з обгрунтуванням специфічних ознак виконавства в регіоні. Зроблено висновок, що не зважаючи на широку поширеність пісень в чоловічому репертуарі - саме жіночий репертуар, поза обрядова сфера виконавства є збереженою найкращим чином та представляє собою найяскравіші зразки. Ключові слова: Полтавщина, обрядовий фрольклор, поза обрядовий фольклор, виконавство, специфіка.

Tormulation of the problem.Poltava region

belongs to the Dnieper part of Ukraine, which is considered by such scientists as A. Ivanytskyi [4], O. Murzina [5], O. Bench [6] - a center of national type of folk performance. Meanwhile, the territory of the Middle Dnieper (Kyiv region, Cherkasy region, Poltava region) is significant and differs in its performing traditions in its various villages, districts, cities. The folklore of Poltava region is characterized by a wide variety both in genre and in terms of performance.

Analysis of research and publications. Summarized information about ethnographers who studied the Poltava region at the turn of the XIX and XX centuries is contained in the source [1]. From the side of the musical life development of Poltava region in the same period it is worth noting the work [2]. The song folklore of the designated cultural and ethnographic area is presented in a thorough work [3], which was the main source of information for our exploration.

Highlighting previously unresolved parts of a common problem. Poltava, as a component of the Dnieper Ukraine, has been reflected in a number of scientific works of domestic scientists, both art and other fields. However, such an aspect as a concise and generalized analysis of spe- cific folklore traits, genres, performance specificity is mainly concentrated in large-scale works. This complicates the understanding of the very essence of the folklore of the above-mentioned territory.

Formulation of the aims of the article. Brief analysis of specific features of song folklore of Poltava region and main stages of its development.

Presenting the main research material. The complex historical and political path of Poltava region is reflected in the cultural and artistic development of the region. Documented information about the cultural development of the Poltava region can be found in the written references of the engineer G. de Boplan (1648-1650) in the "Description of Ukraine or the regions of the Kingdom of Poland lying between the borders of Moscow and Transylvania" with additional information about the Ukrainians' attitude, customs and military capability", which also describes calendar-lunch creativity and family-folklore of Ukrainians. Ethnographic mentions of a general descriptive nature are reflected in the writings of the famous traveler J. Güldenstadt, and later we find information in the travel notes of V. Zuiev. The above-mentioned facts about the cultural development and art of this region are general and descriptive.

The first detailed recorded information about folklore, in particular about its musical component occur- 
ring in the XIX century, is reflected in three works by V. Miloradovich. The first, "Wedding songs in the Lubny district of Poltava province" is an attempt of meaningful systematization, which proceeds from the order of the wedding ritual. The second "Folk Rites and Songs of Lubnydistrict" from a series of ethnographic works is a comparison of pagan and Christian worldviews of the local population and their combination, which was reflected in various festive activities. The third work "Life and Being of the Lubny Peasant" did not aim to describe the musical traditions, but in the chapters of the work there is a description of the musical traditions and songs.

Since the beginning of the XX century, the ethnographic information of the region has become more detailed and represents a new level of research. It is worth noting the works of F. Vovk "The Ukrainian nation in its past and present", "Eth- nographic peculiarities of the Ukrainian people", which thoroughly investigate the folk traditions of the Ukrainian people, including Poltava region.

Detailed studies of song folklore of Poltava region with indication of the respondent, place of recording and peculiarities of performance begin in the XX century, in the postwar period. Such research has tremendous scientific value.

Thus, the researcher [7] distinguishes two types of distribution of song folklore performance in Poltava region: male songs and female songs. The male type outside the ritual singing of Poltava region includes ballads and historical songs, the authentic variants of cossack, chumak, orphan ballads in male performance are unanimous, it should be noted that later variants may have two or three voices.

The second type (female) performance includes songs from the lyrical sphere.

\section{Chronology of Ethnographic and Folklore Studies in the Poltava Region}

Table 1 in the XVII-XX Centuries

\begin{tabular}{|c|c|c|}
\hline Researcher & \begin{tabular}{c|} 
Years of \\
assembly
\end{tabular} & Localization, work title, fixed genres \\
\hline \multicolumn{3}{|r|}{ XVII Century } \\
\hline G. de Boplan & $1648-1650$ & $\begin{array}{l}\text { Poltava region } \\
\text { Description of Ukraine or the regions of the Kingdom of Poland lying } \\
\text { between the borders of Moscow and Transylvania }\end{array}$ \\
\hline \multicolumn{3}{|r|}{ XVIII Century } \\
\hline J. Güldenstadt & 1775 & Poltava region \\
\hline V. Zuiev & 1781 & $\begin{array}{l}\text { Poltava region } \\
\text { Travel notes of Vasilii Zuiev from St. Petersburg to Kherson in } 1781 \text { and } \\
1782 \text { «edding songs in the Lubny district of Poltava province" } \\
\text { Life and Being of the Lubny Peasant }\end{array}$ \\
\hline \multicolumn{3}{|r|}{ XIX Century } \\
\hline M. Gogol & $1829-1834$ & A book of all sorts, or the Encyclopedia of Manuscript. Recorded 150 songs \\
\hline P. Lukashevich & until 1836 & $\begin{array}{l}\text { Part of Poltava province } \\
\text { Malorussian and Redrussian folk thoughts and songs }\end{array}$ \\
\hline P. Chubynskyi & $1872-1878$ & $\begin{array}{l}\text { Poltava region } \\
\text { «Works of the Ethnographic-Statistical Expedition to the West-Russian } \\
\text { Territory»; } 17 \text { letters to L. Maykov and letter to P. Semenov) are dated } \\
\text { December 5, } 1869 \text { - December 8, 1878, } 32 \text { letters to F. Osten-Saken, } \\
\text { M. Venyukov, P. Semenov, L. Maykov }\end{array}$ \\
\hline M. Dragomanov & $1874-1876$ & $\begin{array}{l}\text { Historical songs of the Malorussian people (by V. Antonovich); Malorussian } \\
\text { folk tales and stories }\end{array}$ \\
\hline V. Miloradovich & 1890 & $\begin{array}{l}\text { Poltava region } \\
\text { «Wedding songs in the Lubny district of Poltava province»; } \\
\text { Folk Rites and Songs of Lubnydistrict; }\end{array}$ \\
\hline $\begin{array}{l}\text { A. Yedlichka } \\
\text { V. Yedlichka }\end{array}$ & 1881 & $\begin{array}{l}\text { "Selection of favorite Russian folk songs arranged for one voice with piano } \\
\text { accompaniment" }\end{array}$ \\
\hline \multicolumn{3}{|r|}{ XX Century(the postwar period) } \\
\hline K. Kvitka & & $\begin{array}{l}\text { Lokhvitsa, Dubny, Myrhorod, Piryatin, Priluka, Poltava } \\
\text { Ritual songs, children's songs, ballads }\end{array}$ \\
\hline V. Vasylenko & 1906 & Poltava region \\
\hline F. Vovk & $1908-1911$ & $\begin{array}{l}\text { Poltava region } \\
\text { "The Ukrainian nation in its past and present", "Ethnographic features of } \\
\text { the Ukrainian people" }\end{array}$ \\
\hline Y. Liniova & 1905 & $\begin{array}{l}\text { The experience of phonograph recording of Ukrainian folk songs // Works of } \\
\text { the Musical and Ethnographic Commission ... T. 1. M., } 1906\end{array}$ \\
\hline M. Lysenko & & $\begin{array}{l}\text { Lubny, Khorly, Poltava districts } \\
\text { Ballads, Ritual Songs }\end{array}$ \\
\hline Konoschenko-Grabenko & 1909 & $\begin{array}{l}\text { Lubny, Khorly, Poltava districts } \\
\text { «Ukrainian songs with notes» }\end{array}$ \\
\hline V. Shepotiev & 1915 & "Folk songs recorded in Poltava province" \\
\hline $\begin{array}{l}\text { S. Lipovets } \\
\text { D. Onishchenko }\end{array}$ & 1920 & Gadyach, Lubny district \\
\hline
\end{tabular}

Source: systematized by the author on the basis of [3; 7; 9; 11] 
In a thorough work [3], which is a summary of research scientists IMFE of M. Rylskyi much of the study is devoted, also, to children's songs. Children's songs of Poltava region are performed both by children and adults (by family members). Such songs represent two spheres: non- ritual and ritual.

The sphere outside the ritual kind of folk songs songs-entertainments - is performed by mom or dad while entertaining a child, as well as children's playful songs.

It is worth noting that the above genres from the female, male and children's repertoire, namely lullabies, songs-entertainments, varieties of male ballads - all belong to one-voice music.

According to the type of invoice, the song folklore of Poltava region should be divided into one-voice and many-voice songs, which in turn are divided into homophonic-harmonic and polyphonic type of presentation. Folk songs are performed both solo and in a group, it should be noted that band songs do not always have a polyphonic type of presentation, and there is also a subtle performance of the group songs.

Solo performance is found in a minority of cases, and is mainly related to outside the ritual sphere of song folklore and to female performance (lullabies performed by a woman personally and which according to [8] are characterized by quiet dynamics and repetitive motif), lyrical songs-monologues. One-voice songs also include ceremonial lamentations [7], mostly performed by women.

Two-voice and three-voice songs are distinguished by polyphonic type. The two-voice songs have a typical Central Ukraine structure where the lower voice (mainly in female performance) is the base and the upper one is the sub-voice. Depending on the location, this type of output is called a tonchik or a horiak.
Here is a quote by O. Murzina, which fully reveals the peculiarities of the voice output characteristic of the Middle Dnieper region: "Voice output is a melodic decoration of the Dnieper songs (with spacious melodic moves overcoming the tightness of formulaic chants). Rising melodic strokes extend the sound range, and therefore intervals of tertiary or quartile above the upper main support are not uncommon in the output of the Dnieper songs" [5].

Poltava's polyphonic songs mostly belong to non-ritual lyrics and female type of performance. As in most parts of the Middle Dnieper region, songs of homophonic harmonic composition and polyphonic composition stand out. Analysis of song folklore of Poltava region represented in fundamental work [3] allowed us to form an opinion about the prevalence of tertiary second, which sometimes increases to the interval of quarts or quintas in a considerable number of two-voice songs. Such a tertiary second is characteristic throughout the Middle Dnieper.

Songs of three voices in the same work are often a tertiary second with an octave duplication of melody, where the base (bass) and melody (sub-voice) form an octave, and the middle voice is produced by the tertiary above the base (bass). O. Murzina noted that: "The practice of mixed ensemble, characteristic of the Dnieper region, provides the sound completeness of the texture and helps to distinguish a clear bass line that is common for men and women" [5].

Thus, the three-voice songs are distinguished by a well-defined bass (lower voice, not necessarily male - more often female), middle voice, which performs the function of the main melody and the upper voice, which is a melismatic decoration of the main, middle voice.

Let us consider some expressive performance features of the song performance of Poltava region:

Distribution of the genre system by gender

Table 2

\begin{tabular}{|c|c|c|}
\hline \multicolumn{3}{|c|}{ Distribution of the genre system by gender } \\
\hline Male songs & Female songs & Children's songs \\
\hline $\begin{array}{c}\text { Ballads (Orphan, Chumak) } \\
\text { Cossack songs } \\
\text { Historical songs } \\
\text { Slave songs }\end{array}$ & $\begin{array}{c}\text { Lullabies } \\
\text { Songs-entertainment } \\
\text { Tank-game songs of the calendar-ritual cycle (hayivka, } \\
\text { petryvchani, Kupala, mermaid, spring) } \\
\text { Labor (pre-harvesting, harvesting) } \\
\text { Wedding songs (most of their varieties during all stages of the } \\
\text { wedding) } \\
\text { Ballads on social issues } \\
\text { Love lyrics }\end{array}$ & $\begin{array}{c}\text { Christmas carols } \\
\text { New Year songs } \\
\text { Melankas }\end{array}$ \\
\hline
\end{tabular}

Specific performance characteristics of the folklore song of Poltava region

Table 3

\begin{tabular}{|c|c|}
\hline Ritual folklore & Non-ritual folklore \\
\hline $\begin{array}{l}\text { In the petryvchani songs- the final sound (Gu!) } \\
\text { In Kupala songs - the final sound (Uh!) } \\
\text { In wedding songs - the final sound (I, Uh, Gu) } \\
\text { In wedding songs - singing at the same time in two } \\
\text { tones. The singing of the solo is performed in one key, } \\
\text { and the group chorus is performed in the other key. } \\
\text { In wedding songs - the use of a "thin voice" or a tonchik. } \\
\text { In the calendar-ritual songs of the winter cycle - the use } \\
\text { of a "thin voice" or a tonchik. }\end{array}$ & $\begin{array}{l}\text { In lullabies - Inserting the "i" or "e" at the end of a } \\
\text { stanza and singing them in a seconds or tertiaries } \\
\text { In children's entertainment songs - the use of "chugging" } \\
\text { (oh, chug-chug, oh che-che). Recitative, repetitive melody } \\
\text { In lyrical songs from the female repertoire: } \\
\text { decoration of melodic line of different kind of } \\
\text { melismatics, both in one- and many-voice songs; } \\
\text { - Dorian system; } \\
\text { - Syllable dividing in the middle and at the end of the } \\
\text { stanza; } \\
\text {-use of insertion words; } \\
\text { - the predominance of voracious vocabulary }\end{array}$ \\
\hline
\end{tabular}

Source: systematized by the author on the basis of [3; 4; 5] 
Conclusions from this study and per- songs in the male repertoire - it is the female spective. The song folklore of Poltava region is repertoire, outside the ritual sphere of perforcharacterized by genre and performance variety. mance, it is best preserved and represents the However, despite the widespread distribution of most striking examples.

\section{References:}

1. Mykytchuk, S. (2009). Rozvytok etnohrafii v Naddniprianskii Ukraini naprykintsi XIX - na pochatku XX stolittia (istoriohrafichnyi aspekt) [The development of ethnographyinthe Dnieper Ukraine in thelate XIX early XX century (historiography aspect)]. Narodnatvorchist ta etnohrafiia, no. 4-5, pp. 119-125. (in Ukrainian)

2. Lytvynenko, A. (2006). Muzychna kultura Poltavshchyny XIX - pochatku XX stolittia v aspektakh rehionalnoho dzhereloznavstva [Musical culture of Poltava region of XIX - early XX centuries in aspects of regional source studies]. (PhD Thesis). Kyiv: Muzychna akademiia Ukrainy. (in Ukrainian)

3. Yefremova, L. (2016). Narodni pisni Poltavshchyny (z kolektsii zbyrachiv folklore) [Folk songs of Poltava region (from collections of folklore collectors)]. Kyiv: Lohos. (in Ukrainian)

4. Ivanytskyi, A. (2015). Obriadovyi muzychnyi folklor Serednoi Naddniprianshchyny: zhanrovo-rehionalna antolohiia [Ritual musical folklore of the Middle Dnieper region: genre and regional anthology]. Vinnytsia: Nova Knyha. (in Ukrainian)

5. Murzina, O. (2014). Serednia Naddniprianshchyna v istorychnomu konteksti formuvannia tradytsi i problem etnomuzykolohii [Middle Dnipro region in the historical context of the formation of the tradition]. Problem of ethnomusicology, no. 9, pp. 12-38. (in Ukrainian)

6. Bench-Shokalo, O.H. (2002). Ukrainskyi khorovyi spiv: aktualizatsiia zvychaievoi tradytsii [Ukrainian Choral Singing: Updating the Customary Tradition]. Kyiv : Ukrainskyi svit. (in Ukrainian)

7. Yefremov, Ye. Poltava region. Available at: http://bervy.org.ua/2014/12/poltavschyna (accessed: 15.09.2019). (in Ukrainian)

8. Hryn, Yu. (2009). Narodna pisnia Poltavshchyny u naukovii spadshchyni V. Shchepotieva [Folk song of Poltava region in the scientific heritage of V. Shepotiev]. Music history of Poltava region. Poltava: POIPPO. (in Ukrainian)

9. Kvitka, K. (2005). Ukrainski narodni melodii [Ukrainian folk tunes]. Kyiv: Naukove vydannia. (inUkrainian)

10. Kvitka, K. (2010). Zibrannia prats: Pryzhyttievi publikatsii (1902-1941) [Collected Works: Lifetime Publications (1902-1941)]. Lviv. (in Ukrainian)

11. Pyzhianova, N. (2016). Retrospektivnyj analiz issledovanija pesennogo iskusstva Cherkasskogo regiona [Retrospective analysis of song art study of Cherkasy region]. Bulletin of Nish university, no. 7, pp. 483-493. (in Russian) 